\title{
Strategi Pengembangan Agribisnis Teh PT Perkebunan Tambi Kabupaten Wonosobo
}

\section{Strategy for Developing Tea Agribusiness at PT Perkebunan Tambi in Wonosobo Regency}

\author{
Satria Eka Pratama ${ }^{1^{*}}$, Hendrik Johannes Nadapdap ${ }^{2}$ \\ ${ }^{1,2}$ Program Studi Agribisnis Fakultas Pertanian dan Bisnis Universitas Kristen Satya Wacana \\ *Email: hendrik.nadapdap@uksw.edu
}

\begin{abstract}
This research aims to 1) Know the strengths and weaknesses as well as opportunities and threats of internal and external factors at Tambi Plantation, Wonosobo Regency. 2) Formulating alternative choices of tea business development strategies that can be recommended at PT Tambi Plantation, Wonosobo Regency. The implementation of this study began in February until March 2019 and the research location was at PT Perkebunan Tambi. The data analysis technique in this study uses the IFE, EFE, IE, SWOT and QSPM matrices. The results of this study are PT Perkebunan Tambi has 10 strength factors, 5 weakness factors, 7 opportunity factors and 5 threat factors faced by the company and 10 alternative development strategies are recommended for the company.
\end{abstract}

Keywords: Development, Plantation, PT Tambi Plantation, Strategy, Tea

Disubmit :10 Oktober 2018 ; Diterima : 15 November 2018 ; Disetujui : 08 Januari 2019

\section{PENDAHULUAN}

Sektor agribisnis memiliki peran yang penting dalam pembangunan perekonomian nasional. Hal ini dikarenakan sektor agribisnis cukup berperan dalam Pertumbuhan Domestik Bruto (PDB). Pada tahun 2017 kontribusi PDB sektor agribisnis dengan angka yang cukup tinggi yaitu sebesar 13,14\% (BPS, 2018). Menurut Saragih dan Sipayung (2006) agribisnis merupakan suatu rangkaian industri yang mencakup sektor pertanian, industri hulu dan hilir pertanian (agroindustri), sektor perdagangan input dan hasil pertanian serta sektor-sektor jasa yang terkait langsung. Pengembangan agribisnis ditujukan untuk mengantisipasi era perdagangan bebas yang menuntut adanya daya saing produk pertanian yang berkualitas dan berkesinambungan (Laura 2010).

Subsektor perkebunan sebagai bagian dari sektor pertanian dapat berperan aktif dalam rangka peningkatan perekonomian nasional. Laju pertumbuhan PDB sektor perkebunan dari tahun 2016 hingga 2017 mengalami kenaikan yang cukup tinggi yaitu 0,99\% dari 3,47\% menjadi 4,46\% (BPS, 2018). Teh merupakan komoditas perkebunan di Indonesia yang memiliki kontribusi besar antara lain menjadi sumber pendapatan petani, menampung ketenagakerjaan, serta mendorong agroindustri pengembangan wilayah dan pelestarian lingkungan.

Pengembangan teh di Indonesia yang telah dilakukan berupa penyediaan benih teh klon unggul, peningkatan ketersediaan sarana produksi, perluasan dan rehabilitasi kebun, pengendalian hama penyakit dan gulma, peningkatan kualitas SDM, peningkatan produksi dan menjaga kontinuitas suplai, peningkatan mutu hasil dan daya saing produk, peningkatan posisi tawar, penataan sistem tataniaga yang transparan, penataan kelembagaan agribisnis teh dari hulu ke hilir, peningkatan dukungan permodalan agribisnis, dan perbaikan regulasi pertehan nasional. 
Salah satu perkebunan teh di Jawa Tengah adalah PT Perkebunan Tambi. PT Perkebunan Tambi berada di Kabupaten Wonosobo. Kabupaten Wonosobo berada pada ketinggian 200 sampai 2,250 meter di atas permukaan laut serta rata-rata suhu udara antara $14,3-26,5^{\circ} \mathrm{C}$. Sehingga dengan kondisi geografis Wonosobo cocok sebagai tempat perkebunan teh. PT Perkebunan Tambi sendiri mengelola tiga unit perkebunan yang terletak di Desa Bedakah, Desa Tambi dan Desa Tanjungsari dengan luas areal 771,8 hektar. Produk yang dihasilkan di PT Perkebunan Tambi berupa teh hitam, teh hijau dan teh kemasan. PT Perkebunan Tambi merupakan salah satu perusahaan yang bergerak dalam bidang produksi teh. Faktor pengembangan usaha menjadi permasalahan bagi perkebunan Tambi karena belum terlalu banyak melakukan pengembangan seperti diversifikasi produk dan belum terlalu banyak melakukan promosi. Salah satu pengembangan yang dilakukan PT Perkebunan Tambi adalah pelatihan K3, dalam rangka menciptakan suatu upaya agar kegiatan yang terjadi di perkebunan Tambi berjalan dengan baik sehingga dapat memicu perkembangan usaha teh.

Penelitian ini secara umum bertujuan untuk merumuskan strategi pengembangan agribisnis teh bagi perkebunan Teh Tambi, Kabupaten Wonosobo, secara rinci tujuan penelitian ini adalah mengetahui kekuatan dan kelemahan serta peluang dan ancaman dari faktor-faktor internal dan eksternal di PT Perkebunan Tambi, Kabupaten Wonosobo, serta merumuskan alternatif pilihan strategi pengembangan usaha teh yang dapat direkomendasikan pada PT Perkebunan Tambi, Kabupaten Wonosobo.

\section{METODE PENELITIAN}

Lokasi penelitian dilaksanakan di PT Perkebunan Tambi, Wonosobo. Pemilihan lokasi penelitian dipilih secara sengaja (purposive) atas dasar pertimbangan bahwa wilayah tersebut berpotensi untuk pengembangan agribisnis teh. Waktu pelaksanaan pengumpulan data dilakukan selama dua bulan pada bulan Februari dan Maret 2019. Penelitian ini merupakan penelitian deskriptif kualitatif. Deskriptif merupakan suatu jenis dalam penelitian suatu objek, kondisi, pemikiran ataupun suatu peristiwa pada masa sekarang (Nazir 2009). Metode penelitian kualitatif adalah suatu metode pendekatan atau penelusuran untuk mengeksplorasi dan memahami suatu gejala sentral. Untuk mengerti gejala sentral tersebut peneliti mewawancarai informan atau partisipan dengan mengajukan pertanyaan yang umum dan agak luas (Raco 2010).

Narasumber dalam penelitian ini meliputi dua macam, yaitu: Informan kunci (Key Informant) adalah seseorang yang memiliki informasi pokok serta memahaminya sehingga dapat membagikan informasi yang diperlukan dalam penelitian dan Informan adalah seseorang yang terlibat langsung dalam kegiatan yang berkaitan dengan topik penelitian. Informan kunci (key informant) yang dipilih dalam penelitian ini sebanyak 1 orang yaitu Kasubag Pengolahan dan informan yang akan digunakan pada penelitian ini sebanyak 2 orang yaitu Kasubag Tanaman dan Kasubag Pemasaran.

Analisis data yang digunakan adalah tahap pertama input data menggunakan matriks IFE dan matriks EFE, tahap kedua pencocokan data menggunakan matriks IE dan matriks SWOT, lalu tahap ketiga pengambilan keputusan menggunakan matriks QSPM. Alat yang digunakan untuk menganalisis data pada tahap input adalah matriks IFE dan matriks EFE. Matriks IFE berhubungan dengan tingkat kepentingan relatif dari faktor-faktor kekuatan dan kelemahan dalam perusahaan, sedangkan matriks EFE berhubungan dengan tingkat kepentingan relatif dari faktor-faktor peluang dan ancaman luar perusahaan. Data yang didapat dari matriks IFE dan EFE akan digunakan untuk dasar analisis pada tahap pengolahan data dan keputusan.

Teknik yang digunakan untuk mengolah data dari hasil input ke perumusan strategi adalah matriks IE dan matriks SWOT. Matriks IE dibuat berdasarkan skor bobot IFE pada sumbu horizontal dan skor bobot EFE pada sumbu vertikal. Matriks IE dikelompokkan menjadi tiga kelompok yang memiliki perencanaan strategi yang berbeda tiap kelompoknya. Pertama kelompok I, II dan IV digambarkan tumbuh dan membangun, pilihan strategi seperti pengembangan pasar dan pengembangan produk merupakan pilihan yang tepat. Kedua kelompok III, V dan VII digambarkan menjaga dan mempertahankan. Lalu yang ketiga 
kelompok VI, VIII dan IX diartikan divestasi perusahaan (pengurangan aset perusahaan). Matriks SWOT merupakan alat untuk mencocokan data faktor internal dan eksternal sehingga dapat membantu merumuskan strategi pengembangan yang tepat.

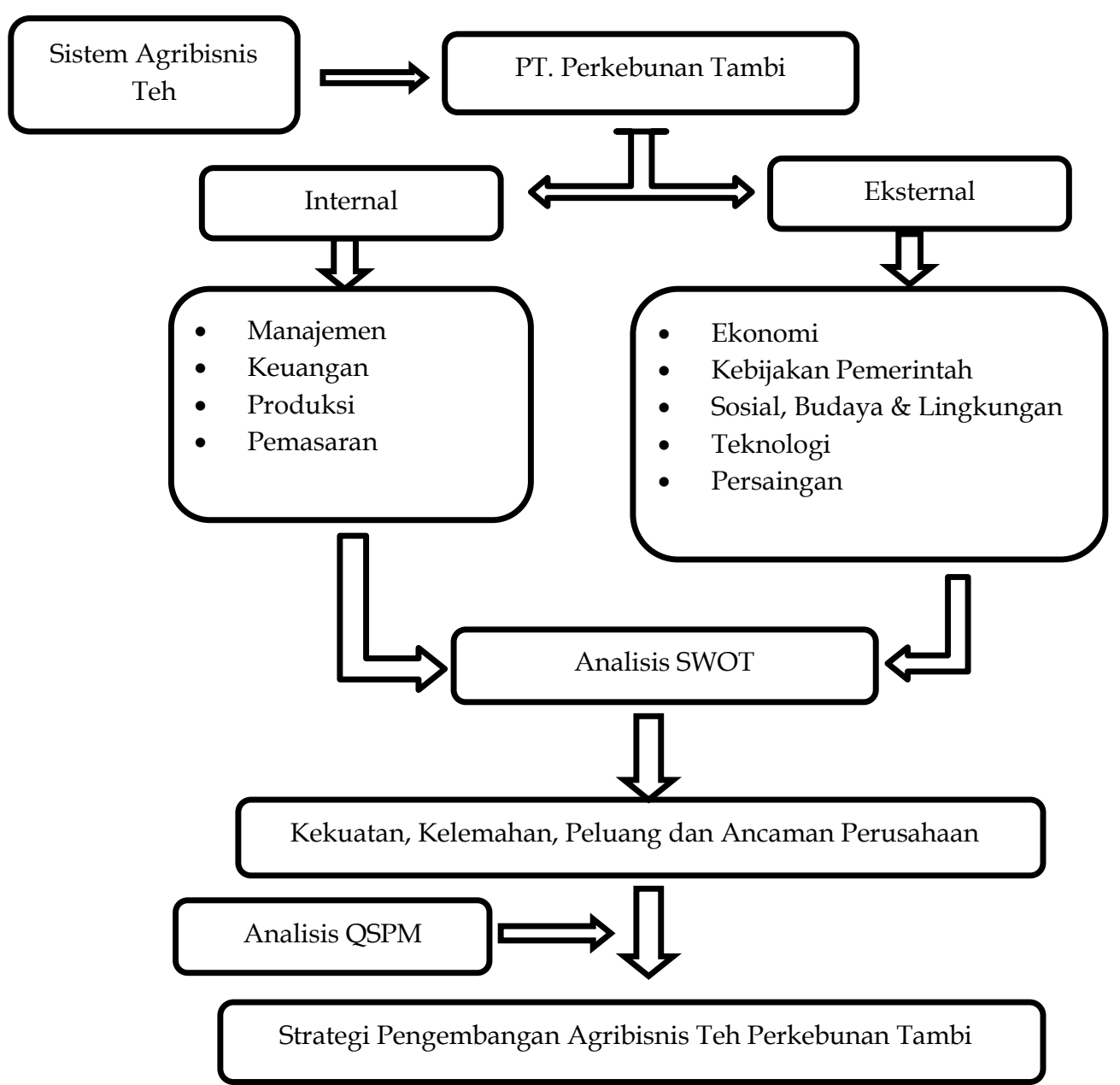

Gambar

Kerangka

1. penelitian

\section{HASIL DAN PEMBAHASAN}

\section{Identifikasi Faktor Internal PT Perkebunan Tambi}

Analisis faktor internal di PT Perkebunan Tambi menghasilkan sepuluh faktor dari kekuatan dan lima faktor dari kelamahan yang dimanfaatkan untuk mengambil peluang serta mengatasi ancaman dari luar perusahaan. Hasil dari analisis faktor-faktor internal didapat dari analisis lingkungan internal yang mencakup aspek manajemen, pemasaran, keuangan dan produksi. Faktor-faktor kekuatan dan kelemahan internal PT Perkebunan Tambi diuraikan pada tabel 1.

Kekuatan utama yang ada pada PT Perkebunan Tambi adalah terdapat pemotivasian kepada karyawan secara teratur, dengan nilai skor 0,269. Variabel tersebut merupakan varibel faktor internal dalam segi kekuatan yang paling penting dalam melaksanakan kegiatan di PT Perkebunan Tambi. Pemberian motivasi kepada karyawan di PT Perkebunan Tambi dianggap penting karena menjadi faktor utama untuk melaksanakan pekerjaan dengan baik dan benar. Karyawan akan lebih termotivasi jika atasan tiap-tiap bagian memperhatikan bawahannya, karena hubungan yang baik antara atasan dan bawahan akan menghasilkan kerja karyawan optimal. Pemotivasian yang diberikan kepada karyawan di PT Perkebunan Tambi dilaksanakan secara teratur setiap hari jum'at setelah melakukan senam pagi. Sedangkan untuk kepala 


\section{Jurnal Penelitian Pertanian Terapan}

bagian dan kepala sup bagian diberikan pemotivasian saat rapat triwulan atau tiga bulan sekali bersama direksi PT Perkebunan Tambi. Untuk kelemahan utama yang ada di PT Perkebunan Tambi adalah pekerja belum memenuhi standar operasional prosedur seperti tidak menggunakan masker, kaos seragam dan sepatu, dengan nilai skor 0,196 . Pekerja belum memenuhi standar operasional prosedur merupakan penghambat dalam melaksanakan kegiatan perkebunan teh Tambi, karena dengan tidak melakukan pekerjaan sesuai standar maka tidak akan menghasilkan produk yang optimal secara kualitas ataupun kuantitas.

Tabel 1. Matriks IFE PT Perkebunan Tambi

No $\quad$ Faktor Strategi Internal $\quad$ Bobot $\quad$ Rating Skor

\section{Kekuatan}

1

Pembagian jobdesk sudah sesuai dengan tugasnya masing-masing secara tepat

Kegiatan PT Perkebunan Tambi sudah berjalan baik karena sudah

2 terdapat rancangan kegiatan perusahaan setiap tahun dan evaluasi kegiatan secara teratur

3 Terdapat pemotivasian kepada karyawan secara teratur

4 Memiliki sertifikat HACCP dan RA

5 Sudah ada penentuan persentase untuk dijual ekspor dan untuk lokal

6 Manajemen keuangan sudah baik dari segi pembagian anggaran setiap bagian dan evaluasi anggaran telah terlaksana dengan baik

$7 \quad$ Fasilitas produksi sudah terkelola dengan baik

8 Teh tambi tidak memerlukan bahan baku dari luar karena memiliki kebun budidaya sendiri

9 Memiliki komoditas teh jenis unggulan

Taste dari produk teh tambi lebih unggul dibandingkan taste teh produk lain

\section{Kelemahan}

11

Lebih diutamakan kesenioran sehingga tenaga kerja yang lebih lama bekerja diprioritaskan

12

Belum melakukan riset pasar ke konsumen di luar Wonosobo terkait produk teh kemasan

13 Belum melakukan promosi yang efektif

Pekerja belum memenuhi standar operasional prosedur seperti tidak menggunakan masker, kaos seragam dan sepatu

15 Pemantauan tanaman teh yang masih kurang

$0,066 \quad 3 \quad 0,198$

$\begin{array}{lll}0,064 & 4 & 0,256 \\ 0,090 & 3 & 0,269 \\ 0,058 & 4 & 0,231 \\ 0,060 & 4 & 0,238 \\ 0,058 & 4 & 0,231 \\ 0,060 & 4 & 0,238 \\ 0,060 & 3 & 0,179 \\ 0,058 & 4 & 0,231 \\ 0,060 & 4 & 0,238\end{array}$

$\begin{array}{lll}0,090 & 2 & 0,179\end{array}$

$0,090 \quad 2 \quad 0,179$

$0,092 \quad 2 \quad 0,183$

$0,098 \quad 2 \quad 0,196$

$0,096 \quad 2 \quad 0,192$ 
Matriks IFE mengidentifikasi faktor-faktor yang meliputi kekuatan (strength) dan kelemahan (weakness) PT Perkebunan Tambi dengan aspek manajemen, keuangan, pemasaran serta produksi. Menurut David, F (2009) apabila nilai total skor yang didapat diatas 2,5 dapat diartikan bahwa perusahaan memiliki kondisi internal yang kuat, sedangkan jika nilai total skor yang didapat dibawah 2,5 perusahaan diketahui memiliki kondisi internal yang lemah Kondisi internal PT Perkebunan Tambi dilihat dari nilai skor pada matriks IFE diatas. Nilai total skor yang didapat sebesar 3,239. Nilai total skor ini lebih besar dari nilai total skor rata-rata sebesar 2,5, yang menunjukan bahwa PT Perkebunan Tambi mempunyai kondisi internal perusahaan yang kuat. Jadi dapat disimpulkan dari hasil analisis faktor internal perusahaan bahwa PT Perkebunan Tambi sudah mampu memanfaatkan kekuatan yang dimiliki untuk mengatasi kelemahan yang ada.

\section{Identifikasi Faktor Eksternal PT Perkebunan Tambi}

Analisis faktor eksternal di PT Perkebunan Tambi menghasilkan tujuh faktor dari peluang yang dapat dimanfaatkan dan lima faktor dari ancaman yang harus diatasi oleh pihak PT Perkebunan Tambi. Hasil dari analisis faktor-faktor eksternal didapat dari analisis lingkungan eksternal yang mencakup aspek ekonomi, kebijakan pemerintah, sosial, budaya dan demografi, teknologi serta persaingan. Faktor-faktor peluang dan ancaman eksternal PT Perkebunan Tambi diuraikan pada tabel 2.

Peluang utama yang ada pada PT Perkebunan Tambi adalah permintaan teh dalam negeri meningkat namun jumlah pemasok teh masih sedikit, dengan nilai skor 0,307 . Variabel tersebut merupakan varibel faktor eksternal dalam segi peluang yang paling penting karena PT Perkebunan Tambi memiliki peluang untuk dapat memasok teh dengan kuantitas yang lebih. Selain itu, dengan jumlah penjualan dengan kuantitas yang lebih tinggi akan menghasilkan keuntungan yang tinggi juga, sehingga mampu menambah pendapatan untuk kas perusahaan. Untuk ancaman utama yang ada di PT Perkebunan Tambi adalah harga produk teh lain lebih rendah daripada produk teh tambi, dengan nilai skor 0,364. Harga produk teh lain yang lebih rendah merupakan salah satu ancaman utama untuk produk teh Tambi, karena kebanyakan masyarakat akan lebih memilih teh yang sudah dulu dikenal dengan harga yang murah.

Tabel 2. Matriks EFE PT Perkebunan Tambi

\begin{tabular}{|c|c|c|c|c|}
\hline No & Faktor Strategi Eksternal & Bobot & Rating & Skor \\
\hline & Peluang & & & \\
\hline 1 & $\begin{array}{l}\text { Permintaan teh dalam negeri meningkat namun jumlah pemasok teh } \\
\text { masih sedikit }\end{array}$ & 0,102 & 3 & 0,307 \\
\hline 2 & $\begin{array}{l}\text { Kenaikan kurs dolar mengakibatkan harga teh naik saat diekspor ke } \\
\text { luar negeri }\end{array}$ & 0,064 & 4 & 0,258 \\
\hline 3 & $\begin{array}{l}\text { Tempat budidaya teh yang baik dengan ketinggian antara 1700-2000 } \\
\text { mdpl }\end{array}$ & 0,064 & 3 & 0,193 \\
\hline 4 & $\begin{array}{l}\text { Masyarakat sekitar perusahaan mendukung adanya PT Perkebunan } \\
\text { Tambi }\end{array}$ & 0,064 & 4 & 0,258 \\
\hline 5 & Pemandangan alam yang bagus di daerah Wonosobo & 0,064 & 4 & 0,258 \\
\hline 6 & $\begin{array}{l}\text { Perkembangan teknologi mesin petik untuk mempermudah panen } \\
\text { daun teh }\end{array}$ & 0,064 & 4 & 0,258 \\
\hline 7 & Perusahaan lain membuka peluang untuk berkerja sama & 0,064 & 3 & 0,193 \\
\hline
\end{tabular}




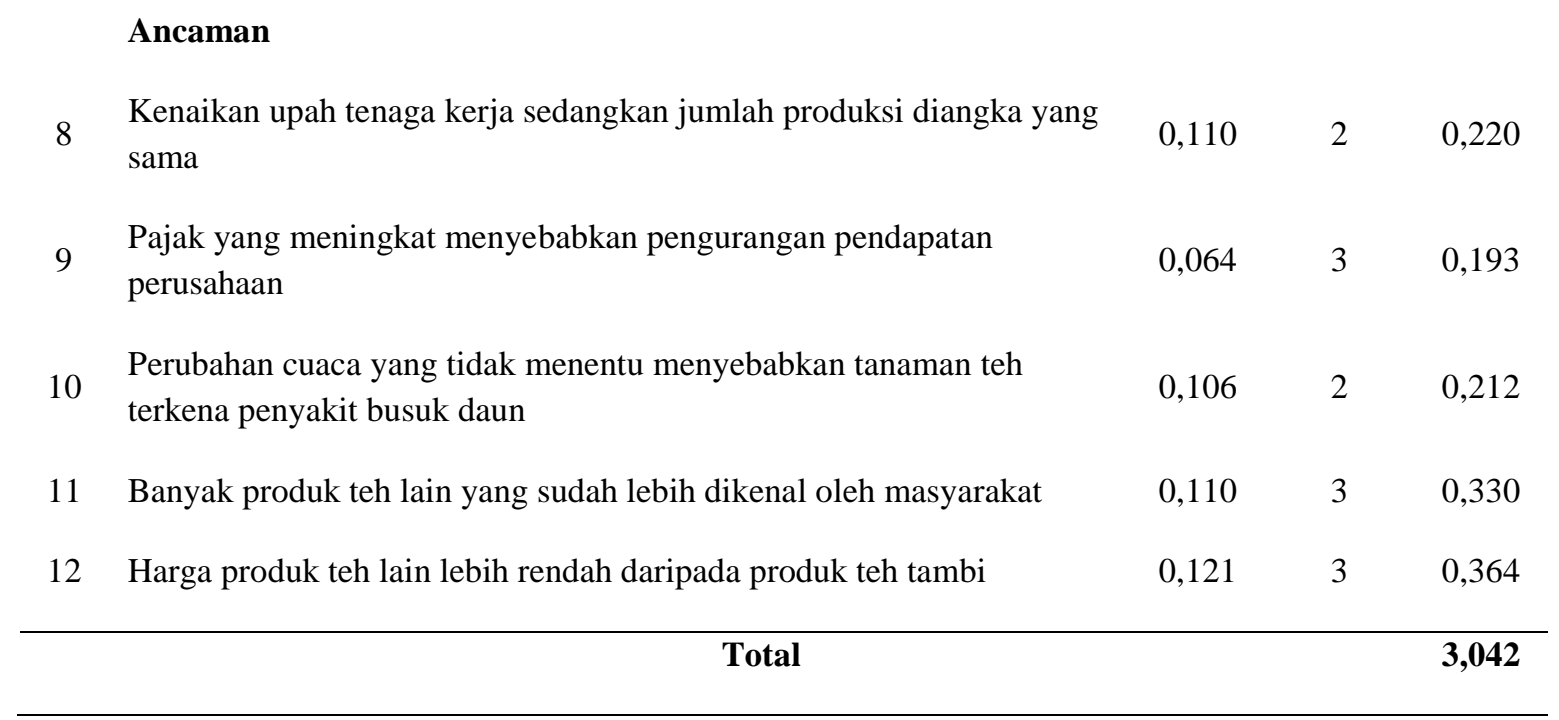

Sumber : Data Primer, 2019

Matriks EFE mengidentifikasi faktor-faktor yang meliputi peluang dan ancaman yang di hadapi PT Perkebunan Tambi dengan aspek ekonomi, kebijakan pemerintah, sosial, budaya dan demografi, teknologi, persaingan. Menurut David, F (2009) apabila nilai total skor yang didapat diatas 2,5 dapat diartikan bahwa perusahaan mampu merespons dengan baik peluang dan ancaman yang ada, sedangkan jika nilai total skor yang didapat dibawah 2,5 perusahaan belum mampu memanfaatkan peluang yang muncul atau mengatasi ancaman yang ada. Kondisi eksternal PT Perkebunan Tambi dilihat dari nilai skor pada matriks EFE diatas. Nilai total skor yang didapat sebesar 3,042. Nilai total skor ini lebih besar dari nilai total skor rata-rata sebesar 2,5, yang menunjukan bahwa PT Perkebunan Tambi mampu merespons peluang dan ancaman dari luar dengan baik. Jadi dapat disimpulkan dari hasil analisis faktor eksternal perusahaan bahwa PT Perkebunan Tambi sudah mampu memanfaatkan peluang yang muncul untuk mengatasi ancaman yang ada.

\section{Perumusan Alternatif Strategi Pengembangan}

Tahap pencocokan dan perumusan alternatif strategi dalam penelitian ini menggunakan analisis matriks IE dan matriks SWOT. Mencocokan faktor-faktor internal dan eksternal PT Perkebunan Tambi yang didapat dari wawancara merupakan kunci untuk menciptakan strategi alternatif yang masuk akal. Matriks IE didapat dari nilai total skor matriks IFE dan matriks EFE yang terdapat pada tahap input.

Total nilai skor IFE PT Perkebunan Tambi adalah 3,239 sedangkan total nilai skor EFE PT Perkebunan Tambi adalah 3,042. Pemetaan masing-masing total nilai skor dari faktor internal dan eksternal menghasilkan posisi PT Perkebunan Tambi berada pada sel ke-1. Hasil dari pemetaan ini menunjukan bahwa PT Perkebunan Tambi memiliki kondisi internal yang kuat dan eksternal yang tinggi. PT Perkebunan Tambi dalam kondisi ini dapat menggunakan strategi tumbuh dan membangun (growth and build) untuk menentukan alternatif strategi yang sesuai dengan keadaan PT Perkebunan Tambi saat ini. Strategi yang cocok untuk diterapkan adalah strategi intensif (intensive strategies) yaitu penetrasi pasar, pengembangan pasar dan pengembangan produk atau menggunakan strategi integrasi (integration strategies). Gambar dibawah ini merupakan hasil dari pemetaan total nilai skor faktor internal dan eksternal yang menunjukan posisi PT Perkebunan Tambi.

Tabel 3. Matriks IE

\section{Total Skor IFE}

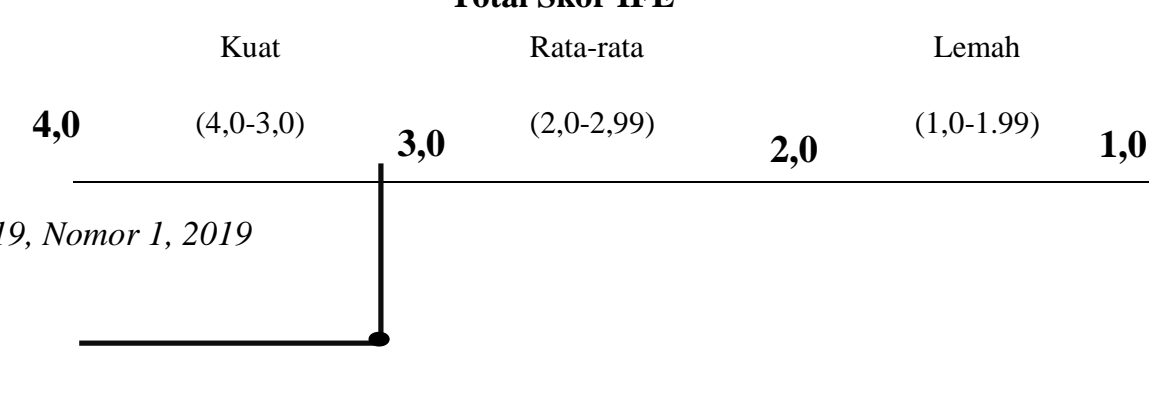


Satria Eka Pratama, dkk : Strategi Pengembangan Agribisnis Teh PT Perkebunan Tambi Kabupaten Wonosobo

\begin{tabular}{|c|c|c|c|}
\hline & I & II & III \\
\hline $\begin{array}{l}\text { Tinggi } \\
(4,0-3,0)\end{array}$ & $\begin{array}{l}\text { Growth and Build } \\
\text { (Tumbuh dan } \\
\text { Membangun) }\end{array}$ & $\begin{array}{l}\text { Growth and Build } \\
\text { (Tumbuh dan } \\
\text { Membangun) }\end{array}$ & $\begin{array}{l}\text { Hold and Maintain } \\
\text { (Pertahankan dan } \\
\text { Pelihara) }\end{array}$ \\
\hline 3,0 & IV & $\mathrm{V}$ & VI \\
\hline $\begin{array}{l}\text { Sedang } \\
(2,0-2,99)\end{array}$ & $\begin{array}{l}\text { Growth and Build } \\
\text { (Tumbuh dan } \\
\text { Membangun) }\end{array}$ & $\begin{array}{c}\text { Hold and Maintain } \\
\text { (Pertahankan dan Pelihara) }\end{array}$ & $\begin{array}{l}\text { Harvest and Divest } \\
\text { (Panen atau Divestasi) }\end{array}$ \\
\hline 2,0 & VII & VIII & IX \\
\hline Rendah & Hold and Maintain & Harvest and Divest & Harvest and Divest \\
\hline $\begin{array}{r}(1,0-1,99) \\
\mathbf{1 , 0}\end{array}$ & $\begin{array}{c}\text { (Pertahankan dan } \\
\text { Pelihara) }\end{array}$ & (Panen atau Divestasi) & (Panen atau Divestasi) \\
\hline
\end{tabular}

Sumber : Data Primer, 2019

\section{- Strategi SO (Strengths-Opportunities)}

[SO1] Meningkatkan kualitas produk teh tambi. Kualitas produk merupakan salah satu faktor penting dalam melakukan agrobisnis teh. PT Perkebunan Tambi memiliki bibit teh unggulan yaitu jenis Sinensis yang berasal dari China. Dengan modal memiliki jenis bibit teh unggulan maka PT Perkebunan Tambi dapat menanam teh dengan jenis yang sama agar kualitas teh yang dihasilkan lebih baik lagi. Produk teh PT Perkebunan Tambi memiliki ciri khas tersendiri yaitu teh tambi memiliki cita rasa teh yang kuat. Strategi ini juga berdampak positif pada penjualan PT Perkebunan Tambi. Karena PT Perkebunan Tambi menjaga dan meningkatkan kualitas produk teh, maka konsumen akan percaya kepada PT Perkebunan Tambi sehingga akan menambah jumlah konsumen dan akan meningkatkan jumlah pendapatan perusahaan. Dari hasil analisis yang dilakukan oleh Sinaga (2008) meningkatkan kualitas produk untuk menghadapi ancaman pesaing dan produk substitusi merupakan alternatif strategi SO, karena hal ini sangat penting dalam mempertahankan pangsa pasar yang sudah dimiliki serta akan bermanfaat untuk menjaring pasar-pasar baru.

[SO2] Mengedukasi masyarakat tentang teh dari mulai budidaya hingga ciri-ciri produk teh yang baik dan bagus. Agar suatu produk dikenal oleh masyarakat atau konsumen maka perusahaan perlu berupaya untuk melakukan kegiatan yang dapat menarik minat masyarakat atau konsumen untuk mengenal produk yang dihasilkannya. Salah satu kegiatan PT Perkebunan Tambi yang dapat menarik minat konsumen adalah melakukan edukasi terhadap masyarakat tentang teh. PT Perkebunan Tambi dapat melakukan kegiatan ini melalui keikutsertaan dalam suatu event, sebagai contoh mengikuti festival teh atau festival lainnya. Dalam acara tersebut PT Pekerbunan Tambi dapat mengedukasi masyarakat atau konsumen tentang teh dimulai dari budidaya hingga pengolahan teh lewat mulut ke mulut dan menyebar brosur, dan secara tidak langsung PT Perkebunan Tambi mempromosikan produk tehnya. Sehingga masyarakat atau konsumen tertarik untuk membeli produk teh Tambi.

[SO3] Menjalin kerja sama dengan distributor yang potensial untuk menambah pangsa pasar. Pemasaran produk Tambi untuk dalam negeri yang dilakukan PT Perkebunan Tambi belum memiliki kekuatan untuk merebut konsumen pasar produk teh dibandingkan dengan produk teh dari perusahaan lainnya. Sehingga perlu adanya upaya untuk menangani permasalahan tersebut, salah satu strategi untuk menangani permasalahan tersebut adalah menjalin kerja sama dengan distributor yang potensial. Menambah jaringan koneksi distribusi merupakan cara yang tepat, karena bekerja sama dengan mereka maka secara tidak langsung PT Perkebunan Tambi sudah menambah pangsa pasar. Memilih calon distributor perlu mempertimbangkan beberapa hal seperti mereka memiliki kekuatan untuk menjual produk ke pasar, serta 
manajemen operasional mereka sudah baik atau belum. Maka dari itu memilih distributor yang potensial untuk diajak bekerja sama juga penting untuk dipertimbangkan. Dari hasil analisis yang dilakukan oleh Wiedjarnarko, et al (2015)memiliki distributor resmi untuk tiap provinsi merupakan alternatif strategi yang bertujuan berjangka panjang, dengan strategi ini maka perusahaan akan melakukan kontak dengan distributor yang dipilihnya sehingga dapat membantu distribusi produk perusahaan tersebut secara berkala.

\section{- Strategi WO (Weakness-Opportunities)}

[WO1] Melatih karyawan sesuai dengan bidang keahliannya dan menetapkan aturan serta memberikan sanksi yang tegas apabila melanggar peraturan. Melakukan pelatihan terhadap karyawan PT Perkebunan Tambi merupakan kegiatan yang perlu dilaksanakan karena adanya pelatihan terhadap karyawan maka pekerjaan yang dilakukan akan baik dan sesuai SOP. Setiap bagian malakukan pelatihan sesuai pekerjaan mereka, jika karyawan di bagian budidaya teh maka diberi pelatihan tata cara budidaya teh yang benar dan baik dan jika karyawan di bagian pengolahan teh maka diberi pelatihan tentang pengolahan teh yang benar dan baik sesuai SOP, dan di bagian lainnya juga diberi pelatihan sesuai bidang pekerjaannya. Maka dari itu perlu peraturan dan sanksi yang ditetapkan PT Perkebunan Tambi untuk karyawan agar melakukan pekerjaan dengan baik. Apabila terdapat karyawan yang bekerja tidak sesuai aturan atau melanggar peraturan maka perlu ditindak lanjuti dengan tegas oleh PT Perkebunan Tambi, agar dapat menghasilkan produk teh yang baik. Dari hasil analisis yang dilakukan oleh Sihaloho (2009) meningkatkan kualitas SDM melalui pelatihan merupakan alternatif strategi SO, strategi ini diusulkan agar ada peningkatkan sumberdaya manusia melalui pelatihan berdasarkan bagian yang mereka kerjakan sehingga mampu memperlancar jalannya proses produksi.

[WO2] Memperluas area penjualan produk teh tambi dengan melakukan ekspansi di tempat wisata Wonosobo. Tempat wisata yang ada di daerah Wonosobo terkenal dengan keindahannya, seperti Telaga Warna, Kawah di Dieng, Telaga Menjer, dll. Banyak pengunjung dari luar Wonosobo yang datang ke tempat wisata saat liburan atau ada acara tertentu. Dengan adanya tempat wisata tersebut maka menjadi peluang untuk PT Perkebunan Tambi untuk menjual produk teh Tambi. Dari hasil analisis yang dilakukan Sihaloho (2009)memperluas usahatani kopi yang berkualitas dan jaringan pemasaran merupakan alternatif strategi SO, strategi ini diusulkan karena ketersediaan lahan yang dimiliki Humbang Hasundutan yang sesuai untuk usaha kopi serta lancarnya akses tranportasi dan keamanan dalam berusaha, sehingga dapat memanfaatkan peluang yang ada untuk melakukan perluasan pemasaran kopi.

[WO3] Penggunaan peralatan terkini untuk meningkatkan kualitas produk. Penggunaan peralatan terkini dapat membantu karyawan untuk melakukan pekerjaan dengan lebih mudah. Dari analisis yang dilakukan oleh Sinaga (2008) meningkatkan kerjasama dengan lembaga-lembaga terkait untuk meningkatkan mutu dan teknologi baru bagi perusahaan merupakan alternatif strategi WT, dengan mengetahui informasi teknologi baru dari lembaga terkait maka akan mempermudah proses produksi teh sehingga diharapkan mampu bersaing dengan pesaingnya. Hal ini sesuai dengan strategi yang diusulkan ke PT Perkebunan Tambi yaitu penggunaan perlatan terkini untuk meningkatkan kualitas produk. Diharapakan dengan adanya startegi tersebut akan meningkatkan jumlah penjualan serta mingkatkan pendapatan perusahaan.

\section{- Strategi ST (Strengths-Threats)}

[ST1] Menambah lahan budidaya teh atau petani-petani mitra. Agar PT Perkebunan Tambi dapat mempertahankan atau bahkan meningkatkan jumlah penjualan maka perlu menambah lahan budidaya teh atau bekerja sama dengan petani teh untuk dijadikan mitra kerja. Selain itu dapat mengurangi permasalahan yang terjadi seperti banyak tanaman teh yang terkena penyakit sehingga produksi berkurang serta mengurangi penurunan pendapatan PT Perkebunan Tambi akibat kenaikan upah tenaga kerja dan pajak. Dengan menambah lahan budidaya teh atau bekerja sama dengan petani teh maka PT Perkebunan Tambi akan meningkatkan jumlah produksi teh sehingga meningkatkan pula pendapatan yang diterima PT Perkebunan Tambi. Adanya bentuk kerja sama antara PT Perkebunan Tambi dengan petani teh juga memberikan dampak positif kepada petani teh. Memberikan kemudahan dalam pendistribusian teh 
merupakan dampak yang jelas akan diterima oleh petani teh karena tidak perlu memikirkan akan dijual ke mana teh hasil produksinya, sehingga penghasilan petani teh akan terjamin. Dari hasil analisis yang dilakukan oleh Sinaga (2008) memperluas areal perkebunan yang masih tersedia merupakan alternatif stratego WO, areal perkebunan yang masih tersedia cukup luas sehingga membuka peluang untuk perusahaan guna meningkatkan kualitas pucuk daun yang lebih baik. Selain itu menurut Atman (2011) penambahan lahan baru akan meningkatkan jumlah produksi suatu produk.

[ST2] Menambah produk pengembangan dari teh tambi seperti teh siap minum. PT Perkebunan Tambi saat ini menjual produk teh dalam bentuk kemasan dan teh yang belum dikemas. Masyarakat yang sedang melakukan suatu kegiatan atau sedang dalam perjalanan dan ingin mengkonsumsi minuman teh perlu membuat teh terlebih dahulu apabila belum tersedia teh yang siap minum, sehingga tidak efisien dan efektif bila harus membuat teh dahulu. Maka dari itu perlu produk pengembangan dari teh yang dapat menangani permasalahan tersebut yaitu membuat produk teh siap minum. Selain membuat teh siap minum, perusahaan dapat memanfaatkan bahan dari bagian tanaman teh untuk dibuat produk lainnya. Manfaat dalam menambah produk pengembangan teh untuk PT Perkebunan Tambi adalah untuk meningkatkan pendapatan PT Perkebunan Tambi, karena teh yang sudah diolah maka nilai jualnya juga akan bertambah. Dari hasil analisis yang dilakukan oleh Nurunisa dan Baga (2011) meningkatkan produksi dan diversifikasi produk teh merupakan alternatif strategi SO, dengan mengunakan bagian lainnya dari tanaman teh serta memanfaatkan perkembangan industri besar yang mengolah produk berbahan dasar teh dapat terjadi peningkatan produksi melalui diversifikasi produk teh.

- Strategi WT (Weakness-Threats)

[WT1] Meningkatkan promosi dengan membuat iklan yang unik dan menarik serta memiliki ciri khas dari produk tambi. Strategi meningkatkan promosi merupakan suatu cara untuk membuat masyarakat atau konsumen minat dalam membeli produk milik perusahaan. PT Perkebunan Tambi belum melakukan promosi yang efektif, sehingga perlu adanya kreativitas dalam melakukan promosi seperti membuat slogan yang menarik dan memiliki ciri khas tersendiri atau dengan mempromosikan lewat media sosial dan elektronik. Adanya kegiatan ini akan meningkatkan penjualan produk teh Tambi serta masyarakat akan lebih mengenal produk yang dihasilkan PT Perkebunan Tambi. Dari hasil analisis yang dilakukan oleh Nurunisa dan Baga (2011) meningkatkan kegiatan promosi produk teh Indonesia merupakan alternatif strategi SO, startegi ini diarahkan untuk meningkatkan brand awareness dan citra produk teh Indonesia terhadap konsumen Internasional.

[WT2] Membuka cabang retail baru di luar Wonosobo. Penjualan teh kemasan PT Perkebunan Tambi masih mencangkup daerah Wonosobo, sehingga daerah luar Wonosobo belum mengetahui produk teh Tambi. Untuk membeli teh Tambi konsumen luar Wonosobo masih harus datang ke Wonosobo. Maka dari itu strategi yang tepat untuk menangani permasalahan itu adalah membuka cabang retail di luar Wonosobo. Membuka cabang dilakukan secara bertahap dimulai dari kota terdekat Wonosobo setelah itu menjalar ke kota-kota besar seperti Yogyakarta, Surabaya, Jakarta, dll. Sehingga konsumen luar Wonosobo bisa menikmati produk teh Tambi.

\section{Penentuan Prioritas Strategi PT Perkebunan Tambi}

Penentuan prioritas strategi didapat berdasarkan penilaian dari narasumber mengenai alternatifalternatif strategi yang sudah dipilih sesuai dengan hasil analisis SWOT. Berdasarkan hasil analisis matriks QSPM dapat dilihat prioritas alternatif strategi yang berkaitan dengan pengembangan agribisnis teh PT Perkebunan Tambi, seperti yang tertera dibawah ini:

1. Menjalin kerja sama dengan distributor yang potensial untuk menambah pangsa pasar (Nilai TAS : 7,354298479)

2. Mengedukasi masyarakat tentang teh dari mulai budidaya hingga ciri-ciri produk teh yang baik dan bagus (Nilai TAS : 7,330211455)

3. Meningkatkan kualitas produk teh tambi (Nilai TAS : 7,326326451) 
4. Melatih karyawan sesuai dengan bidang keahliannya dan menetapkan aturan serta memberikan sanksi yang tegas apabila melanggar peraturan (Nilai TAS : 6,972985348)

5. Memperluas area penjualan produk teh tambi dengan melakukan ekspansi di tempat wisata Wonosobo (Nilai TAS : 6,90480353)

6. Meningkatkan promosi dengan membuat iklan yang unik dan menarik serta memiliki ciri khas dari produk tambi (Nilai TAS : 6,301087801)

7. Menambah lahan budidaya teh atau petani-petani mitra (Nilai TAS : 6,224067599)

8. Penggunaan peralatan terkini untuk meningkatkan kualitas produk (Nilai TAS : 5,962884338)

9. Menambah produk pengembangan dari teh tambi seperti teh siap minum (Nilai TAS : 5,939879565)

10. Membuka cabang retail baru di luar Wonosobo (Nilai TAS : 5,936521812)

\section{KESIMPULAN}

Hasil penelitian ini didapat faktor utama kekuatan PT Perkebunan Tambi yaitu terdapat pemotivasian kepada karyawan secara teratur, dengan nilai skor 0,269, faktor utama dalam kelemahan PT Perkebunan Tambi yaitu pekerja belum memenuhi standar operasional prosedur seperti tidak menggunakan masker, kaos seragam dan sepatu, dengan nilai skor 0,196, faktor utama peluang yang didapat PT Perkebunan Tambi yaitu permintaan teh dalam negeri meningkat namun jumlah pemasok teh masih sedikit, dengan nilai skor 0,307, faktor utama ancaman yang dihadapi PT Perkebunan Tambi yaitu harga produk teh lain lebih rendah daripada produk teh tambi, dengan nilai skor 0,364. Strategi yang didapat dari hasil analisis matriks SWOT berjumlah 10 pilihan alternatif strategi pengembangan. Strategi dengan prioritas utama yang diliht dari hasil matriks QSPM adalah Menjalin kerja sama dengan distributor yang potensial untuk menambah pangsa pasar.

\section{DAFTAR PUSTAKA}

Atman. 2011. Dukungan Teknologi Pengembangan Ubi Kayu Di Sumatera Barat. Jurnal Penelitian Pertanian Terapan, 11 (2): 58-68.

BPS [Badan Pusat Statistika]. 2018. Laju Pertumbuhan PDB Seri 2010 Pada Tahun 2016-2017. http://www.bps.go.id. [10 Desember 2018]

David,F, R. 2009. Manajemen Strategis Konsep, Buku 1, Edisi 12. Jakarta: Selemba Empat.

Laura, R. B. 2010. Analisis Strategi Pemasaran Pasta Ubi Jalar PT Galih Estetika Kuningan Jawa Barat. Institut Pertanian Bogor. Bogor.

Nazir, M. 2009. Metode Penelitian Cetakan Ketujuh. Bogor: Ghalia Indonesia.

Nurunisa, V., dan Baga, M. 2011. Analisis Daya Saing Dan Strategi Pengembangan Teh Indonesia. Jurnal Forum Agribisnis, 2 (1): 33-52.

Raco, J. R. 2010. Metode Penelitian Kulitatif. Jakarta: PT Gramedia Widiasarana Indonesia.

Saragih, B. dan Sipayung, T. 2006. Pembangunan Agroindustri Sebagai Strategi Industrialisasi Di Indonesia. Manado: Konres ISEI.

Sihaloho, Tiur Mariani. 2009. Strategi Pengembangan Agribisnis Kopi Di Kabupaten Humbang Hasundutan Sumatera Utara. Institut Pertanian Bogor. Bogor.

Sinaga, S.E. 2008. Strategi Pengembangan Ekspor Teh Hitam Pada Perkebunan Gunung Mas PTPN VIII Bogor, Jawa Barat. Institut Pertanian Bogor. Bogor.

Hal 28 Volume 19, Nomor 1, 2019 
Satria Eka Pratama, dkk : Strategi Pengembangan Agribisnis Teh PT Perkebunan Tambi Kabupaten Wonosobo

Wiedjarnarko, S., Miftah, A. dan Syahbana. 2015. Strategi Distribusi Produk Teh Siap Saji. Jurnal Manajemen dan Agribisnis, 12 (1): 68-77. 